\title{
Comparison of PI and PR Controller Based Current Control Schemes for Single-Phase Grid-Connected PV Inverter
}

\author{
Trung-Kien $V u^{1}$ and Se-Jin Seong ${ }^{1^{*}}$ \\ ${ }^{1}$ Chungnam National University, Division of Information Communication \\ 단상 계통 연계형 태양광 인버터에 사용되는 PI 와 PR \\ 전류제어기의 비교 분석 \\ 부우충기엔 ${ }^{1}$, 성세진 $^{1^{*}}$ \\ ${ }^{1}$ 충남대학교 정보통신공학부
}

\begin{abstract}
Nowadays, the PV systems have been focused on the grid connection between the power source and the grid. The PV inverter can be considered as the core of the whole system because of an important role in the grid-interfacing operation. An important issue in the inverter control is the load current regulation. In the literature, Proportional Integral (PI) controller, which is normally used in the current-controlled Voltage Source Inverter (VSI), cannot be a satisfactory controller for an AC system because of the steady-sate error and the poor disturbance rejection, especially in high-frequency range. Compared with conventional PI controller, Proportional Resonant (PR) controller can introduce an infinite gain at the fundamental frequency of the AC source; hence it can achieve the zero steady-state error without requiring the complex transformation and the de-coupling technique. Theoretical analyses of both PI and PR controller are presented and verified by simulation and experiment. Both controller are implemented in a 32-bit fixed-point TMS320F2812 DSP processor and evaluated on a $3 \mathrm{~kW}$ experimental prototype PV Power Conditioning System (PCS). Simulation and experimental results are shown to verify the controller performances.
\end{abstract}

요 약 태양광 인버터는 계통과 태양광 시스템 사이의 공통 접속점에 고조파, 플리커, 고주파 노이즈가 없는 고품질 전력을 공급하는 핵심적인 역할을 한다. 일반적으로 비례-적분 (PI: Proportional Integral) 제어기는 정상상태 오차와 낮은 외란 제거 능력으로 인하여 교류 계통에서 만족할만한 성과를 얻지 못하나, 현장에서 이득 설정이 용이하므로 일반적으로 전압형 인버터 (VSI)에서 이용된다고 알려져 있다. 이 논문에서는 산업계에서 일반적으로 사용되는 비례적분 제어기와 교류 계통의 상용주파수에서의 무한대의 이득 값을 가지며, 정상상태 에러 발생을 제거하며, 정지 좌 표계에서 구현할 수 있는 비례-이득 (PR: Proportional Resonant) 제어기의 동작 원리, 설계 기법 등을 비교 분석하였 다. PI와 PR 제어기의 분석 결과를 시뮬레이션과 실험을 통하여 그 타당성을 증명하였다. 두 제어기는 32-비트 고정 소수점 연산을 하는 TMS320F2812 DSP 프로세서를 이용하여 구현하였고, $3 \mathrm{~kW}$ 실험용 프로토타입 태양광 인버터를 제작하여 그 성능을 확인하였다.

Key Words : Photovoltaic, PI controller, PR controller, Single-phase, Grid-connected, inverter

\section{Introduction}

The DC/AC inverter, either single-phase or three-phase design, can be considered as the core of the whole system because of an important role in grid-connected operation. Although current and voltage control scheme are possible and implementable, the current control principle is generally preferred for its excellent dynamic

*Corresponding Author : Se-Jin Seong(sjseong@cnu.ac.kr)

Received May 4, $2010 \quad$ Revised July 20, 2010

Accepted August 10, 2010 
characteristics and its inherent over-current limitation capabilities.

Stationary Proportional Integral (PI) controller is conventionally regarded as unsatisfactory for ac system because of the supposedly unavoidable steady-state amplitude and phase errors. But synchronous PI controller acts on DC signals and can achieve the zero steady-state error with the integral part. However, the signal transformation between stationary and synchronous frame leads the synchronous controller implementation is more complex. Hence, a controller with zero steady-state error in the synchronous frame would have advantages in the implementation.

In order to achieve zero steady-state error, a Proportional Resonant (PR) controller is implemented. Due to an infinite gain at the fundamental frequency, PR controller can achieve the high performance in both the sinusoidal reference tracking and the disturbance rejection. A theoretical comparative analysis of two controllers has been carried out based on current control performance.

\section{Analysis of PI and PR controller}

\subsection{PI controller}

\subsubsection{Ideal and Non-ideal PI controllers}

The transfer function of ideal PI controller is defined as (1). If the first-order low-pass filter with cut-off frequency $\omega_{c}$ is used in synchronous frame, the transfer function of ideal PI controller becomes (2). Equation (2) can be seen as a non-ideal PI controller transfer function and can be used to obtain the non-ideal PR controller.

$$
\begin{aligned}
& G_{I}(s)=K_{p}+\frac{K_{i}}{s}=\frac{K_{p} s+K_{i}}{s}=K_{p}\left(1+\frac{1}{T_{i} s}\right) \\
& G_{I}(s)=K_{p}+\frac{K_{i} \omega_{c}}{s+\omega_{c}}
\end{aligned}
$$

where $\mathrm{K}_{\mathrm{p}}, \mathrm{K}_{\mathrm{i}}$ and $T_{i}=\frac{K_{p}}{K_{i}}$ are the proportional gain, integral gain and integral time constant, respectively, and $\omega \mathrm{c}$ is the cut-off frequency.

The PI controller gains can be calculated based on the symmetric or magnitude optimum criterion[1-3]. The latter method has a fast and non-oscillatory closed-loop time response for a large class of plants[2].

\subsubsection{Digital implementation}

The PI controller in time domain:

$$
u(t)=K_{p} e(t)+K_{i} \int_{0}^{t} e(t) d t
$$

where $u(t)$ and $e(t)$ are the output and the error signal input of the PI controller in time domain.

During a sampling time $T_{s}$, equation (3) can be rewritten as:

$$
u(k)=K_{p} e(k)+K_{i} T_{s} \sum_{k} e(k)
$$

And at the previous sampling point:

$$
u(k-1)=K_{p} e(k-1)+K_{i} T_{s} \sum_{k-1} e(k)
$$

Subtract (4) to (5), we can get

$$
u(k)=u(k-1)+K_{p}[e(k)-e(k-1)]+K_{i} T_{s} e(k)
$$

Equation (6) presents the digital form of the PI controller in DSP programming.

\subsection{PR controller}

\subsubsection{Ideal and Non-ideal PR controllers}

In single-phase system, the popularly reference frame transformation cannot be applied directly. Therefore, an alternative approach of transforming controller in $\mathrm{dc}$ quantities from synchronous to stationary frame is the frequency modulated method. This process can be expressed as $[4,5]$ :

$$
G_{R}(s)=G_{I}^{a c}(s)=\frac{1}{2}\left[G_{I}\left(s+j \omega_{0}\right)+G_{I}\left(s-j \omega_{0}\right)\right]
$$

where $\omega_{0}$ is the $\mathrm{AC}$ frequency.

In (7), $\mathrm{G}_{\mathrm{I}}(\mathrm{s})$ is a low-pass transfer function, this transformation results in a frequency shifting transformation. By using the first-order low-pass filter or the PI controller in synchronous frame, but centered around frequency $\omega_{0}$, we can get (8): 


$$
\begin{aligned}
G_{R}(s) & =G_{I}^{a c}(s)=\frac{1}{2}\left[K_{p}+K_{i} \frac{1}{s+j \omega_{0}}+K_{p}+K_{i} \frac{1}{s-j \omega_{0}}\right] \\
& =K_{p}+K_{i} \frac{s}{s^{2}+\omega_{0}^{2}}
\end{aligned}
$$

Equation (8) can be seen to be an ideal PR controller which achieves infinite gain at the AC frequency $\omega 0$.

To avoid stability problems associated with an infinite gain, an approximating (non-ideal) PR controller using a high-gain low-pass filter is used by substituting the non-ideal PI controller in (2) into (7), the non-ideal PR controller can be obtained as:

$$
G_{R}(s)=K_{p}+K_{i} \frac{\left(\omega_{c} s+\omega_{c}^{2}\right)}{s^{2}+2 \omega_{c} s+\omega_{c}^{2}+\omega_{0}^{2}}
$$

Assuming $\omega_{\mathrm{c}} \ll \omega_{0}$, a simpler approximation is:

$$
G_{R}(s)=K_{p}+\frac{K_{i} \omega_{c} s}{s^{2}+2 \omega_{c} s+\omega_{0}^{2}}
$$

We can adjust the non-ideal PR controller gains to obtain the high enough finite gain for eliminating the voltage tracking error. The PR controller gains can be designed following a step-by-step procedure presented in [6].

\subsubsection{Digital implementation}

By substituting $\quad s=\frac{2}{T_{s}} \frac{1-z^{-1}}{1+z^{-1}} \quad$ (the bilinear transformation) into (10), the discrete transfer function of the PR controller can be given by:

$$
G_{R}(z)=\frac{n_{0}+n_{1} z^{-1}+n_{2} z^{-2}}{1+d_{1} z^{-1}+d_{2} z^{-2}}
$$

where $T_{\mathrm{s}}$ is the sampling time and

$$
\begin{aligned}
& n_{0}=\frac{\left(4+4 T_{s} \omega_{c}+\omega_{0}^{2} T_{s}^{2}\right) K_{p}+4 K_{i} T_{s} \omega_{c}}{4+4 T_{s} \omega_{c}+\omega_{0}^{2} T_{s}^{2}} ; \\
& n_{1}=\frac{\left(-8+2 \omega_{0}^{2} T_{s}^{2}\right) K_{p}}{4+4 T_{s} \omega_{c}+\omega_{0}^{2} T_{s}^{2}} ; \\
& n_{2}=\frac{\left(4-4 T_{s} \omega_{c}+\omega_{0}^{2} T_{s}^{2}\right) K_{p}-4 K_{i} T_{s} \omega_{c}}{4+4 T_{s} \omega_{c}+\omega_{0}^{2} T_{s}^{2}} ; \\
& d_{1}=\frac{-8+2 \omega_{0}^{2} T_{s}^{2}}{4+4 T_{s} \omega_{c}+\omega_{0}^{2} T_{s}^{2}} ; \quad d_{2}=\frac{4-4 T_{s} \omega_{c}+\omega_{0}^{2} T_{s}^{2}}{4+4 T_{s} \omega_{c}+\omega_{0}^{2} T_{s}^{2}}
\end{aligned}
$$

The digital form of the PR controller can be:

$$
\begin{aligned}
y(k) & =n_{0} u(k)+n_{1} u(k-1)+n_{2} u(k-2)- \\
& -d_{1} u(k-1)-d_{2} u(k-2)
\end{aligned}
$$

where $u(k)$ is the error input and $y(k)$ is the output of the PR controller.

\section{Single-phase grid-connected PV inverter control technique}

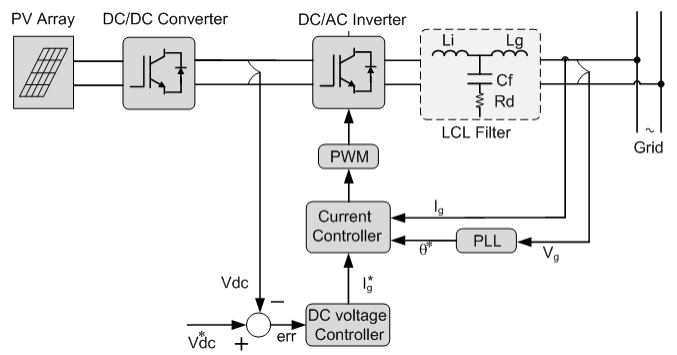

[Fig. 1] Single-phase grid-connected PV inverter system

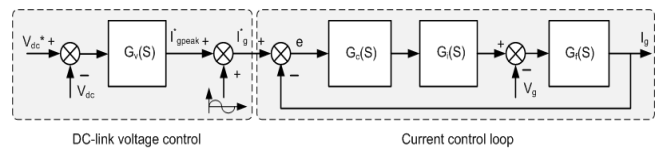

[Fig. 2] Equivalent block diagram of current control scheme

\subsection{Current control scheme}

A single-phase grid-connected PV PCS using has built as shown in Fig. 1 where its equivalent current control block diagram is depicted in Fig. 2. The relationship between input and output of current control system in Fig. 2 can be obtained as:

$$
\begin{aligned}
& I_{g}=H_{i}(s) I_{g}^{*}-H_{g}(s) V_{g} \\
& H_{i}(s)=\frac{I_{g}}{I_{g}^{*}}=\frac{G_{c}(s) G_{i}(s) G_{f}(s)}{1+G_{c}(s) G_{i}(s) G_{f}(s)} \\
& H_{g}(s)=\frac{I_{g}}{V_{g}}=\frac{G_{f}(s)}{1+G_{c}(s) G_{i}(s) G_{f}(s)}
\end{aligned}
$$

where $G_{c}(s)$ is the controller transfer function. $G_{c}(s)$ is (1) in case of PI controller and is (10) in case of PR controller; $\mathrm{G}_{\mathrm{i}}(\mathrm{s})=\mathrm{K}$ is the inverter transfer function. Assuming the switching frequency is high enough to neglect the inverter dynamics, the PWM inverter can be represented by a gain for a simplicity of analysis; 


$$
G_{f}(s)=\frac{R_{d} C_{f} s+1}{L_{i} L_{g} C_{f} s^{3}+\left(L_{i}+L_{g}\right) R_{d} C_{f} s^{2}+\left(L_{i}+L_{g}\right) s} \text { is the }
$$

LCL-filter transfer function with damping resistor.

In steady state, the PI controller has a finite gain at the fundamental frequency, so the second term of (12) cannot be neglected but can be eliminated by using de-coupling technique. However, PR controller introduces an infinite gain, then the first term approaches the inverter current reference and the second term approaches zero.

The PR controller based closed-loop transfer function of current control system shown in Fig. 2 can be obtained as:

$$
H_{i_{R}}(s)=\frac{A_{3} s^{3}+A_{2} s^{2}+A_{1} s+A_{0}}{B_{5} s^{5}+B_{4} s^{4}+B_{3} s^{3}+B_{2} s^{2}+B_{1} s+B_{0}}
$$

where

$$
\begin{aligned}
& A_{3}=R_{d} C_{f} K_{p} K \\
& A_{2}=K\left[K_{p}+\left(2 K_{p}+K_{i}\right) \omega_{c} R_{d} C_{f}\right] \\
& A_{1}=K\left[\left(2 K_{p}+K_{i}\right) \omega_{c}+K_{p} R_{d} C_{f} \omega_{0}^{2}\right] \\
& A_{0}=K K_{p} \omega_{0}^{2} \\
& B_{5}=L_{i} L_{g} C_{f} \\
& B_{4}=\left(L_{i}+L_{g}\right) C_{f} R_{d}+2 L_{i} L_{g} C_{f} \omega_{c}
\end{aligned}
$$

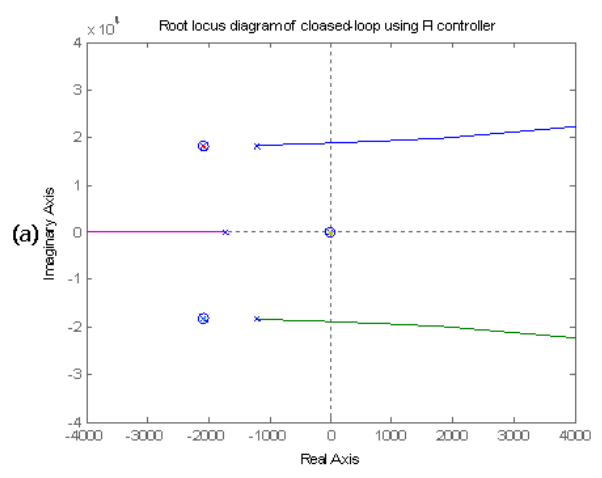

$$
\begin{aligned}
& B_{3}=\left(L_{i}+L_{g}\right)\left(1+2 \omega_{c} C_{f} R_{d}\right)+L_{i} L_{g} C_{f} \omega_{0}^{2}+K K_{p} C_{f} R_{d} \\
& B_{2}=\left(L_{i}+L_{g}\right)\left(2 \omega_{c}+C_{f} R_{d} \omega_{0}^{2}\right)+K K_{p}+\left(K_{i}+2 K_{p}\right) K C_{f} R_{d} \omega_{c} \\
& B_{1}=\left(L_{i}+L_{g}\right) \omega_{0}^{2}+K K_{p} C_{f} R_{d} \omega_{0}^{2}+\left(K_{i}+2 K_{p}\right) K \omega_{c} \\
& B_{0}=K K_{p} \omega_{0}^{2}
\end{aligned}
$$

while PI controller based closed-loop transfer function is obtained in (17):

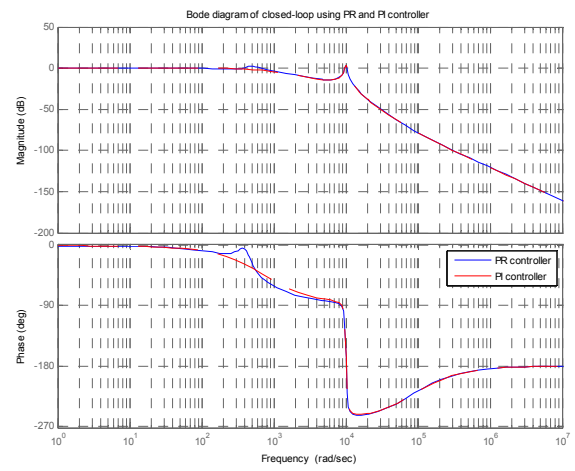

[Fig. 3] Bode diagram of closed-loop transfer function using PI $(\mathrm{Kp}=10, \mathrm{Ki}=50)$ and $\mathrm{PR}(\mathrm{Kp}=15$, $\left.\mathrm{Ki}=200, \omega_{c}=15 \mathrm{rad} / \mathrm{s}\right)$ controller

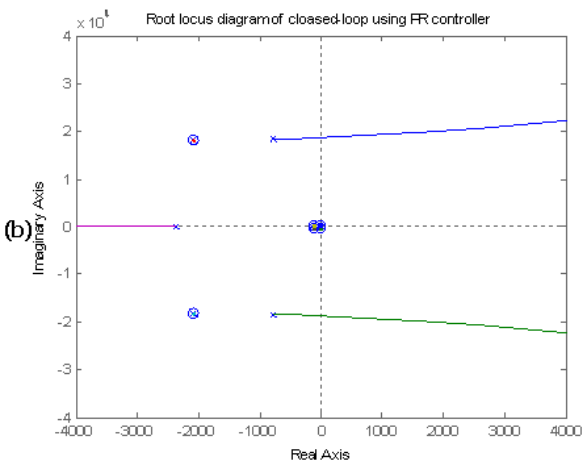

[Fig. 4] Root locus diagram of system using (a) PI and (b) PR controller

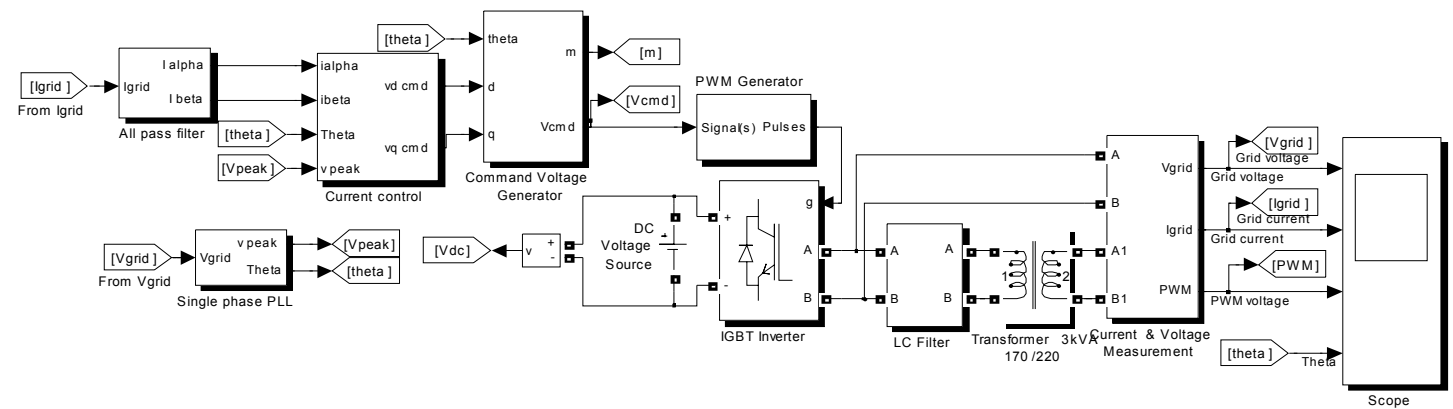

[Fig. 5] Matlab/Simulink model of single-phase grid-connected PV inverter 


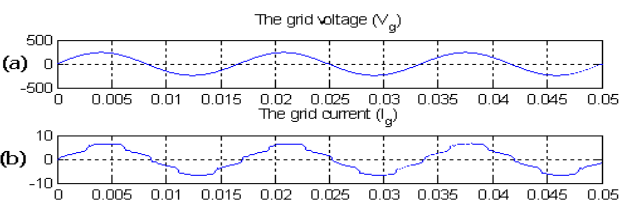

(a)

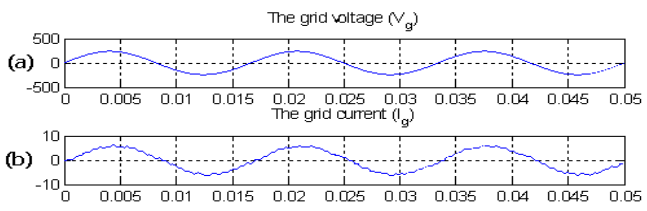

(b)

[Fig. 6] Grid voltage and current using (a) PI controller; (b) PR controller

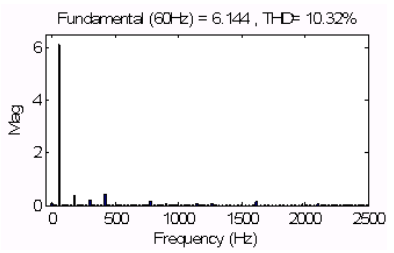

(a)

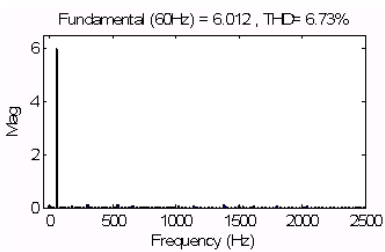

(b)

[Fig. 7] FFT analysis and THD value of grid current using (a) PI controller; (b) PR controller

$$
H_{i_{I}}(s)=\frac{C_{2} s^{2}+C_{1} s+C_{0}}{D_{4} s^{4}+D_{3} s^{3}+D_{2} s^{2}+D_{1} s+D_{0}}
$$

where $C_{2}=R_{d} C_{f} K_{p} K ; \quad C_{1}=\left(K_{p}+K_{i} R_{d} C_{f}\right) K$

$C_{0}=K K_{i}$

$D_{4}=L_{i} L_{g} C_{f} ; \quad D_{3}=\left(L_{i}+L_{g}\right) C_{f} R_{d} ;$

$D_{2}=L_{i}+L_{g}+K K_{p} C_{f} R_{d} ; \quad D_{1}=K\left(K_{p}+K_{i} C_{f} R_{d}\right)$

$D_{0}=K K_{i}$

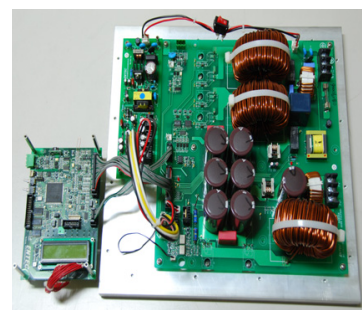

[Fig. 8] (a) 3kW PV PCS experimental prototype

[Table 1] PV PCS parameters

\begin{tabular}{|l|l|}
\hline Grid voltage $\mathrm{Vg}$ & $220 \mathrm{~V} / 60 \mathrm{~Hz}$ \\
\hline DC voltage $\mathrm{Vdc}$ & $400 \mathrm{~V}$ \\
\hline Inverter-side filter inductor $\mathrm{Li}$ & $2 \mathrm{mH}$ \\
\hline Grid-side filter inductor $\mathrm{Lg}$ & $0.86 \mathrm{mH}$ \\
\hline Filter capacitor Cf & $5 \mu \mathrm{F}$ \\
\hline Filter damping resistor $\mathrm{Rd}$ & $2.5 \Omega$ \\
\hline Switching frequency fsw & $10 \mathrm{kHz}$ \\
\hline
\end{tabular}

Fig. 3 shows the bode diagrams of closed-loop systems based on PI and PR controller, where PR controller can introduce an infinite gain at the fundamental frequency.

By choosing the VSI switching frequency higher than system frequency, the inverter will have negligible impact on the control loop dynamic and supply voltage is assumed as sinusoid, the current closed-loop control stability can be analyzed with classical methods such as Nyquist and root locus.

Fig. 4(a) and (b) show the root locus diagrams of PI and PR controller based systems. Fig. 3 and Fig. 4 verified the stability of the system based on PI and PR controller.

\section{Simulation results}

The Matlab/Simulink model of the single-phase grid-connected PV inverter system is shown in Fig. 5. The parameters used in simulation are listed in Table 1.

Fig. 6 (a) and (b) show the simulation responses of the system by using the PI and PR controller, respectively. Fig. 6(a) shows the grid voltage and current using PI controller. The grid voltage and current using PR controller are shown in Fig. 6 (b).

Fig. 7(a) and (b) show the frequency analysis of the grid current and its THD value by using the PI and PR 
controller, respectively.

The simulation results show that PR controller can track the sinusoidal reference and mitigate the harmonics better than PI controller. It is noted that all waveforms are in phase.

\section{Experimental results}

The prototype of $3 \mathrm{~kW}$ single-phase grid-connected PV PCS is shown in Fig. 8 where the controller is implemented fully in a 32-bit fixed-point DSP TMS320F2812. The PWM pulses are generated through the internal pulse generator of the DSP with a switching frequency of $10 \mathrm{kHz}$.

Voltage and current signals are measured by using the 12-bit resolution of internal analog-to-digital converter in the DSP. Also a four-channel 8-bit digital-to-analog converter has been used for debugging.

Fig. 9(a) and (b) show the grid voltage in channel 1 $(250 \mathrm{~V} / \mathrm{div})$ and grid current in channel $4(10 \mathrm{~A} / \mathrm{div})$ by using the PI and PR controller, respectively. It can be

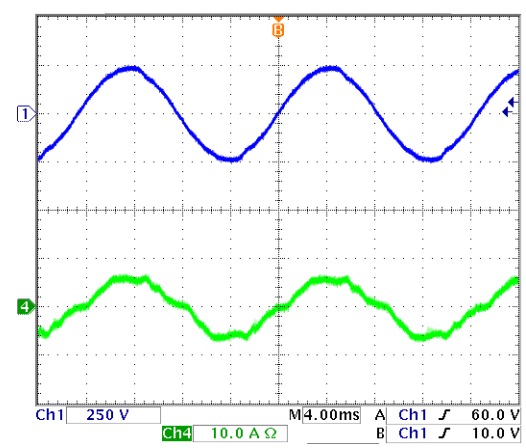

(a) seen that the grid current waveform in Fig. 9(b) is nearly perfect sinusoid. It is noted that the experimental results show a good agreement with the simulation results and both waveforms are in phase.

The frequency analysis and THD values of grid current using the PI and PR controller are shown in Fig. 10(a) and (b), respectively.

When compared between all the experimental results mentioned above, it is can be shown that PR controller can achieve the steady-state performance better than PI control scheme in current-controlled based inverter control scheme.

PR controller can overcome drawbacks of PI controller: inability to track a sinusoidal reference with zero steady-state error and poor disturbance rejection capability.

\section{Conclusions}

In this paper, a comparison between the conventional PI and PR controller based on current control has been

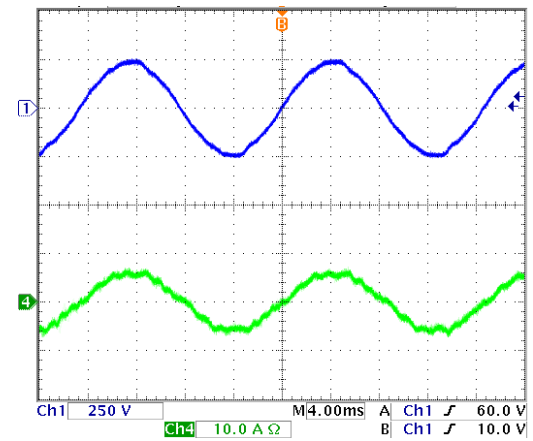

(b)

[Fig. 9] Grid voltage and current implementation results using (a) PI controller; (b) PR controller

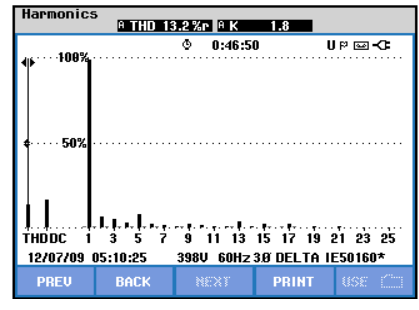

(a)

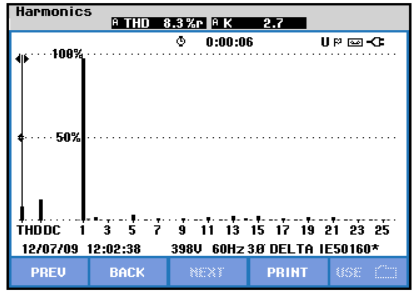

(b)

[Fig. 10] Harmonic order and THD value of grid current using (a) PI controller; (b) PR controller 
presented. The theoretical analysis has been performed that PR controller has some advantages when compared with PI controller and it can enable the implemented control system to achieve a high performance. Simulation and experimental results of $3 \mathrm{KW}$ PV PCS prototype system verified the performance of these controller. Furthermore, these controllers are suitable distributed generation units, not only photovoltaic but also the other power generation system, such as small wind turbine, fuel-cells.

\section{References}

[1] Astrom, K. J. and T. Hagglund, "PID controllers: Theory, Design and Tuning", Instrument Society of America, Second edition, 1995.

[2] Jeffrey W. Umland and Mohammed Safiuddin, "Magnitude and Symmetric Optimum Criterion for the Design of Linear Control Systems: What Is It and How Does It Compare with the Others?", IEEE Transaction on Industry Applications, Vol. 26, Iss. 3, pp. 489-497, June 1990.

[3] Satja Lumbar, Damir Vrancic and Stanko Strmcnik, "Comparative study of decay ratios of disturbannce-rejection magnitude optimum method for PI controllers", ISA Transaction, Vol. 47, pp.94-100, 2008.

[4] Zmood, D.N., Holmes, D.G. and Bode, G.H., "Frequency-domain analysis of three-phase linear current regulators", IEEE Transactions on Industry Applications, Vol. 37, No. 2. pp. 601-610, 2001.

[5] R. Teodorescu, F. Blaabjerg, M. Liserre and P. C. Loh, "Proportional-resonant controllers and filter for grid-connected voltage-source converters, IEE Proceeding Electric Power Applications, Vol. 153, Iss. 5, pp. 750- 762, 2006.

[6] Trung-Kien Vu and Se-Jin Seong, "PR Controller based Current Control Scheme for Single-Phase Inter-Connected PV Inverter", Journal of the Korean Academic Industrial Society, Vol. 10, No. 12, pp. 3587-3593, 2009.

[7] Yong-Seok Lee, Dong-Min Lee and Jun-Keun Ji, "Performance Comparison of Single-Phase PLL Algorithms Using Virtual 2-Phase Strategy", Journal of the Korean Academic Industrial Society, Vol.8, No.2, pp.219-225, 2007.

\section{Trung-Kien $\mathrm{Vu}$}

[Regular member]

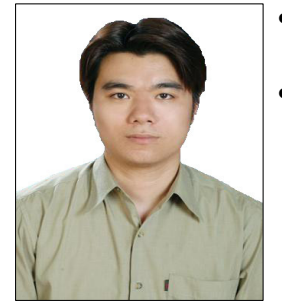

- Aug. 2005 : Chungnam National Univ., Electronics Eng., MS

- Aug. $2005 \sim$ current : Chungnam National Univ., Electrical Eng., Ph.D candidate

$<$ Research Interests $>$

His research interests are in the areas of power electronics control and renewable energy system.

Se-Jin Seong

[Regular member]

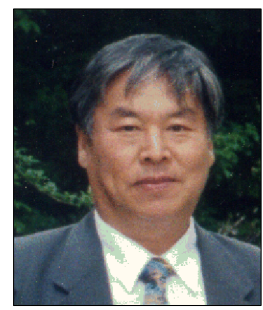

- Feb. 1975 : Seoul National Univ., Electrical Engineering, MS

- Feb. 1988 : Tokyo Industrial of Technology, Electrical Eng., $\mathrm{PhD}$

- Feb. $1988 \sim$ current : Chungnam National Univ., Dept. of Electrical Eng., Professor

$<$ Research Interests $>$

His research interests include design, modeling and analysis of DC-DC converter, Cycloconverter, Electric machine control and Microprocessor application 